\title{
ANALYSIS OF PECULIARITY OF USAGE OF AUSTRIAN GERMAN IN SOCIOLINGUISTIC ASPECT
}

\author{
Mykola Karpik \\ Institute of Philology \\ Taras Shevchenko National University of Kyiv \\ 64/13 Volodymyrska str., Kyiv, Ukraine, 01601
}

\begin{abstract}
The article presents the application of sociolinguistic methods of language study. The proposed research aimed at analyzing the functions of the Austrian variant of the German language in public contexts and disclosing some peculiarities of its use. The issue was addressed by analyzing sociolinguistic and statistic data that we had acquired in 2009-2019. A work with informants was one of the stages of our research. Within the framework of the study of Austrian German we surveyed 102 Austrian respondents, native speakers of the language variant, who represent various social groups and reside in different regions of Austria.

The analysis of the received responses showed that the majority of respondents comprehend the concept Austriacism not only in theory, but in practice as well for the bulk of Austriacisms, given as examples in the questionnaire, were known for the informants.

The respondents gave predominantly affirmative answers to the question "Do you consider Austriacisms to be the recognized word stock of the standard language?" The use of Austriacisms is also majorly not considered obsolete, hens we can conclude, that Austrian German is a modern colloquial language. These results demonstrate the positive attitude to Austriacisms. Approximately half of the surveyed (49\%) showed no awareness of Record 10 on the use of the specific Austrian terms in the German language and this result is seen quite expected. Only $7 \%$ of the surveyed were able to name the number of expressions in this Record. Other responses allow us to address Austriacims as an intrinsic part of Austrian culture and history.

A surprising response we received to the question "Would you like Austriacisms to be used by the residents of other German speaking countries?" given by $40 \%$ of the respondents answering Yes. However, the following responses show that the Austrians consider Austriacisms a factor of identity formation, so they would object to the usage by the non-Austrians.

Therefore, the hypothesis, formed at the beginning of our research, has found some evidence to support it. The results of experimental use of Austriacisms make it possible to draw the following conclusions:

Austrian German is an essential however secondary means of communication in Austria; its use reflects Austrian social reality and national culture. Austrian German acts as an element of Austrian national identity, thus, a further research on its communicative role is an essential task for modern German Studies.
\end{abstract}

Keywords: sociolinguistic survey, work with informants, Austrian German.

DOI: $10.21303 / 2504-5571.2019 .001077$

\section{Introduction}

The issue of national variability of the German language has been a subject for scrutiny by a number of linguists. In particular, it is a polycentric model of German studies, proposed by Michael Klein and supported later by Peter Wiesinger, Rudolph Muhr and Richard Schrodt. This resulted in a decline of the unicentric approach to study the development of German in Europe. Soviet and post-soviet linguists found objective for their research in the issue of language variability in the second part of the 20th century, namely these were Belousova [1980], Gaievska [1969], Domashniev [1967, 1983], Zhluktenko [1981], Ostapovych [1999], Stepanov [1979], Sulym [1994], Shveitser [1976] et al.

Quite a similar polycentric approach to German studies was applied by a number of researchers, including Ulrich Ammon [1995], Jan-Hendrik Leerkamp [2003], Jutta Ransmayr [2006], Sedlaczek Robert [2004], Andreas Weiss and Gerlinde Weiss [2007], and Peter Wiesinger [1995] and others. These studies predominantly demonstrate a new method in investigating linguistic systems. It presupposes the change in the vector of academic research from an abstract ideal 
and actually non-existent language to its concrete living embodiment [1]. According to the common interpretation by the abovementioned linguists, the national varieties (or variants) of the language are certain forms of adapting a unified language to conditions, needs of social development and traditions of native speakers; it is a specific form of the common language functioning [2].

Sociolinguistics is an area, where sociology and linguistics intersect. It studies connections and relations between the language and the society. This definition can be completed by William Bright's statement that sociolinguists aim at finding systematic correlation of the language structure and the structure of society, and even to disclose causal relations in this or that direction [3].

The interest in sociolinguistic issues is caused inter alia by a number of generic factors as well as by the specificity of particular data. The relations between language and society are in a constant change, hence the axioms, formed as a result of the analysis of language and social character of the linguistic phenomena, have a nature of premises; the mechanism of the patterns, described by these maxims, requires a substantial research on the lingual material. We can distinguish two principal sociolinguistic issues: social differentiation of the language and causality in the language development. Sociolinguistics borrows its methods from sociology, social psychology and mathematical statistics. William Labov is considered to be one of the first sociolinguists to regard experiment as an essential stage in sociolinguistic research [4].

The material, attained as a result of the experiment, requires sociolinguistic interpretation which permits determining connections between the language and social institutes. The purpose of sociolinguistics is to study the way the language is used and how changes in the society influence the language.

We based our operational hypothesis on the assumption that in Austria, the Austrians speak Austrian German differentiated and with diverse intensity in various public spheres.

The aim of the sociolinguistic study is to analyze functions of Austrian German in public spheres and also to identify the peculiarities of its use. This task was fulfilled analyzing sociolinguistic and statistic data we had collected in 2009-2019.

\section{Materials and Methods}

One of the stages in our research was the work with informants. We had designed a questionnaire which became a part of the pool of methods that were used in collecting sociolinguistic data. In our work, we interrogated 102 native speakers, representing various social groups and residing in urban areas and federated states of Austria, and also in townships. The respondents were suggested to fill in the questionnaire (Table 1).

Table 1

Sociolinguistic survey: peculiarities in the use of Austrian German

\begin{tabular}{l|c}
\hline \multicolumn{1}{c|}{ Geschlecht } & \multicolumn{1}{c}{$\mathbf{1}$} \\
\hline Alter & \\
\hline Wohnort & \\
\hline Ausbildung & \\
\hline Berufsbereich & \\
\hline Ist Deutsch Ihre Muttersprache? & \\
\hline Kennen Sie den Begriff Austriazismus? & \\
\hline Wussten Sie, dass es ein „Protokoll Nr. 10 über die Verwendung spezifisch österreichischer Ausdrücke der deutschen & \\
Sprache im Rahmen der Europäischen Union“ gibt, welches beim EU Beitritt Österreichs unterzeichnet wurde? & \\
\hline Wissen Sie, wie viele Wörter auf dieser Liste stehen? &
\end{tabular}


Continuationa of Table 1

\begin{tabular}{|c|c|c|c|}
\hline & 1 & & 2 \\
\hline \multicolumn{3}{|l|}{ Kennen Sie diese Wörter? } & \\
\hline Beiried & Faschiertes & Hüferl & \\
\hline Kren & Melanzani & Paradeiser & \\
\hline Rostbraten & Weichseln & Nächtigung & \\
\hline Schani & Eierschwammerl & Erdäpfel & \\
\hline Fisolen & Grammeln & Karfiol & \\
\hline Lungenbraten & Marillen & Nuss & \\
\hline Obers & Powidl & Ribisel & \\
\hline Topfen & Vogerlsalat & Ähne & \\
\hline Naderer & Occasion & Pfusch & \\
\hline \multicolumn{4}{|l|}{ Suchtgift } \\
\hline \multicolumn{4}{|c|}{ Verwenden Sie die folgenden Wörter in der Umgangssprache mündlich, schriftlich oder •beides? } \\
\hline \multicolumn{4}{|c|}{ Meinen Sie, dass die Austriazismen zu der gegenwärtigen deutschen Sprache gehören? } \\
\hline \multicolumn{4}{|c|}{ Glauben Sie, dass die Austriazismen ein anerkannter Bestandteil der Standardsprache sind? } \\
\hline \multicolumn{4}{|c|}{ Nehmen Sie die Verwendung von Austriazismen als Archaismus? } \\
\hline \multicolumn{4}{|c|}{ Wollen Sie, dass die Austriazismen auch von anderen Deutschsprechenden verwendet werden? } \\
\hline \multicolumn{4}{|c|}{ Was ist für Sie österreichische Sprache? } \\
\hline \multicolumn{4}{|c|}{ Schreiben Sie Ihre Assoziationen zu den Wцrtern } \\
\hline \multicolumn{4}{|l|}{ Marillen - } \\
\hline \multicolumn{4}{|l|}{ Aprikosen - } \\
\hline \multicolumn{4}{|l|}{ Ähne - } \\
\hline \multicolumn{4}{|l|}{ Großvater - } \\
\hline \multicolumn{4}{|l|}{ Erdäpfel - } \\
\hline \multicolumn{4}{|l|}{ Kartoffel - } \\
\hline \multicolumn{4}{|l|}{ Mädel - } \\
\hline Mädchen - & & & \\
\hline
\end{tabular}

The first part of the form contained the questions characterizing the respondents 1. Age. 2 . Gender. 3. Place of Residence. 4. Education. 5. Occupation.

\section{Result}

In our survey, we worked only with the German speakers, so we did not include the responses from non-native speakers in our research. The respondents come from six regions: Lower Austria (32\%), Upper Austria (25\%), Vienna (21\%), Styria (7 \%), Tyrol (5\%), and Salzburg (12\%). The majority of the respondents are in the age group 31-60 years, $60 \%$ of the answers we received from women. The surveyed predominantly have university degrees. Concerning occupation, the majority works in the sphere of education, culture and social work (55\%).

The next question in the form was "Do you know the term 'Austriacism'?"

We wanted to find whether the term was familiar to the informants. The result was obvious as 91 people gave affirmative answers, which makes approximately $90 \%$ of the questioned.

"Do you know about the existence of Record 10 on the use of the specific Austrian German terms in EU?"

With this question we wanted to clarify whether the respondents were aware of the legal status of Austriacisms. About one half of the surveyed showed no awareness in this question.

The next question expanded on the previous one:

"Do you know the number of the words in Record 10?" 
The prevailing number of the surveyed, 93\%, did not know the exact number of the words in the Record, however some informants made assumptions about this concern and stated that the expressions denoted mostly foodstuff.

"Do you know that 'Paradeiser' is an Austriacism?"

With this question we tried to ascertain that the informants know some Austriacisms. The majority said yes in $88 \%$ of the cases.

In the question, "Are the following words familiar to you?" we made a list of approximately 30 Austriacisms, out of which 21 were taken from Record 10:

Beiried (Rostbeef) - roast beef; Eierschwammerl (Pfifferlinge) - chanterelles; Erdäpfel (Kartoffel) - potatoes; Faschiertes (Hackfleisch) - minced meat; Fisolen (grüne Bohnen) - green beans; Grammeln (Grieben) - cracklings; Hüferl (Hüfte) - ham; Karfiol (Blumenkohl) - cauliflower; Kohlsprossen (Rosenkohl) - Brussels sprouts; Kren (Meerettich) - horseradish; Lungenbraten (Filet) - filet; Marillen (Aprikosen) - apricots; Melanzani (Auberginen) - eggplant; Nuss (Kugel) - a part of the leg of beef, veal or pork; Obers (Sahne) - cream; Paradeiser (Tomaten) - tomatoes; Powidl (Pflaumenmus) - plum jam; Ribisel (Johannisbeeren) - currants; Rostbraten (Hochrippe) - rib; Topfen (Quark) - cottage cheese; Vogerlsalat (Feldsalat) - lamb's lettuce; Weichseln (Sauerkirschen) - sour cherries. Six more Austriacism we took from the list in Ebner's dictionary Ähne (Opa) - grandfather, Naderer (Verleumder) - slanderer, Nächtigung (Übernachtung) - overnight stay, Occasion (günstiges Sonderangebot) - special offer, Pfusch (Schwarzarbeit) - unreported employment, Schani (Diener, guter Freund) - valet, close friend; Suchtgift (Rauschgift, Drogen) - drugs.

The survey demonstrated that the informants are familiar with Austriacisms from Record 10, and the Austriacisms from another group are mostly known to the surveyed. The word Ähne, which is a bit outdated and denotes "grandfather", is the least known term.

The next question was Do you use all the mentioned words? Do you use them in oral or the written speech?

As the question had quite general character, the responses were general as well. The majority answered "Yes, in both oral and written forms."

To the question "Do you consider Austriacisms to belong to Modern German?"100 out of 102 respondents gave affirmative answers.

"Do you consider Austriacisms to be the recognized word stock of the standard language?"

Here opinions were opposed, as $60 \%$ of respondents gave answer "Yes."

"Do you consider the use of Austriacisms obsolete?"

Most respondents did not regard Austriacisms as a dated form, with only $20 \%$ viewing these expressions as archaic.

"Would you like Austriacisms to be used by German speakers from other countries?"

Here, $60 \%$ of the surveyed did not wish that other German speaking countries residents would use Austriacisms in their speech. Two respondents stated that only if those speakers lived on the territory of Austria.

"What does Austrian German mean for you?"

The respondents were unrestricted in their answers trying to either define Austrian German or express their subjective view of the language.

"Sprachwissenschaftlich gibt es zwar kein "Östtereichisch" sondern nur die österreichische Varietät." -"From the point of view of the science, there is no such thing as the Austrian language; there exists only the Austrian variant of the multicentric German language."

"Eine Standardvarietät des Deutschen.”- "A variant of Standard German."

"Österreichisches Deutsch (im Gegensatz zu Bundesdeutsch)."-“Austrian German (Contrasted to Standard High German)."

“"“̈̈stereichisch”, wie es im größten Teil des Landes gesprochen wird, zählt man zum Bairischen." - "The so-called Austrian German spoken on the extensive territory of Austria is actually Bavarian German."

"Ein identitätsstiftender und sinngebender Bestandteil der Österreicher" - "An intrinsic part of identity and essense for the Austrians."

"Österreichisch ist das bessere Deutsch." - "Austriann is the best variant of German." 
"Eine Dichter- und Schriftstellersprache, die Ausdruck hat." - "The expressive language of poets and writers."

"Ja an sich klingt Österreichisch ganz gut. Aber irgendwie unmännlich finde ich.... ist aber vielleicht auch eine Frage der Gewohnheit." - "Austrian German itself sounds good. However, it is not masculine enough, in my opinion. Probably it's just a question of a habit."

"Österreichisch ist das schönere Deutsch." - "Austrian German is a more beautiful German language."

The last question of the questionnaire "Give your associations to the words" presupposed finding connotations to Austriacisms and their Standard German equivalents. Our concern was to find whether Austriacisms acquire additional connotative meaning.

Many responses reflect a certain amount of independence of linguistic consciousness, for instance.

People associate Marillen (apricots) with Marillenknödel (dumplings with apricots), Marillenmarmelade (apricot jam) and Marillenmarmeladepalatschinken, while "“Aprikosen" - muss ich sagen, wenn ich mit Ausländern spreche (I must say "Aprikosen" when I speak with foreigners)."

On the use of the words Mädel and Mädchen (girl, young lady),one of the reporters noted that Mädchen is a common term for addressing a young women, while Mädel has a load of negative connotations, connected with National Socialist ideology, i.e. Bund Deutscher Mädel (The League of German Girls). In our opinion, however, such lingual manifestation is common predominantly for older demographics.

This rather unambiguous preference for Austriacism indicates a special linguacultural peculiarity of Austrians.

However, some respondents noted, that they saw no difference between using Standard German expressions and their Austrian equivalents; both variants have the same connotations for them. One respondent stated that Austrian terms seem obsolete for him and he doubted that children to-day would understand the word Knabe (lad). He himself is 45 year old and he personally would not use this term.

\section{Discussion}

Summarizing our survey we would like to draw attention to the fact that we worked with 102 respondents. This sample is quite meager and we can make conclusions, based solely on it and are unable to extrapolate the results on the population of Austria in whole. This sample included men and women of different age groups, coming from various Austrian states. These persons have different occupations, most have university degrees and all are native German speakers.

The analysis of the responses, given to the questionnaire, showed that the majority of the surveyed knew the term 'Austriacism' not only in theory, but used it in practice as well. The terms, listed in the questionnaire, were by and large familiar to the informants. The majority stated that they used these terms both in oral and written speech.

The positive attitude to this issue can be seen in the affirmative responses to the question "Do you consider Austriacisms to be the recognized word stock of the standard language."

The majority of the respondents did not consider the phenomenon of Ausriacisms in use obsolete; hence, here we can draw a conclusion, that Austrian German is a modern colloquial language. The acquired results demonstrated the constructive concept of Austriacisms in the minds of the Austrians.

Quite an expected result was that approximately half of the surveyed show no awareness of Record 10 on the use of the specific Austrian terms in the German language. This percentage (49\%) was acquired predominantly due to the academic degrees of the respondents. Only $7 \%$ of the surveyed were able to name the number of expressions in this Record. These two questions were posed to make sure that the Austrians were familiar with these issues in European Union and were aware of their legal status.

The other answers lead us to the conclusion that the majority regarded Austriacisms as a part of Austrian culture and history. A surprising response we received to the question "Would you like Austriacisms to be used by the residents of other German speaking countries?" The answer "Yes" was given by $40 \%$ of the respondents. However, the following replies show that the Austrians consider Austriacisms a factor of identity formation, so they would object to their use by the non-Austrians. 


\section{Conclusions}

Thus, the hypothesis, formed at the beginning of our research, has found some evidence to support it. The results of experimental use of Austriacisms make it possible to draw the following conclusions.

Austrian German is an important secondary channel of communication in Austria. Its use is both an inseparable component of Austrian social reality and a valuable component of the national culture. Austrian German is an important factor of the national identity, so the further study of its communicative role is an essential objective for modern German studies.

\section{References}

[1] Ostapovych, O. (2004). Natsionalna mentalnist u dzerkali avstriyskoho varianta nimetskoi movy. Inozemni movy v navchalnykh zakladakh, 1, 174-185.

[2] Romanenko, O. V. (2009). Natsional'niy variant politsentrichnyh yazykov kak sovokupnaya struktura natsional'noy rechi. Vesnik Bashkirskogo universiteta, 14 (2), 407-410

[3] Brayt, U. (1975). Vvedenie: parametry sotsiolingvistiki. (Novoe v lingvistike. Vyp. VII. Moscow, 34-41. Available at: http:// www.philology.ru/linguistics1/brayt-75.htm

[4] Labov, W. (2010). Principles of Linguistic Change. Wiley. doi: https://doi.org/10.1002/9781444327496

[5] Ammon, U. (1995). Die deutsche Sprache in Deutschland, Österreich und der Schweiz: Das Problem der nationalen Varietäten. de Gruyter. doi: https://doi.org/10.1515/9783110872170

[6] Belikov, V. I., Kryisin, L. P. (2001). Sotsiolingvistika. Moscow: Ros.gos. gumanit. un-t.

[7] Ebner J. (2008). Österreichisches Deutsch. Eine Einführung. Duden Österreichisches Deutsch. Mannheim, Leipzig, Iwen, Zürich: Dudenverlag, 6-48.

[8] Gordon, M. J. (2006). Interview with William Labov. Journal of English Linguistics, 34 (4), 332-351. doi: https://doi.org/ $10.1177 / 0075424206294308$

[9] Leerkamp, J.-H. (2003). Die österreichische Varietät der deutschen Sprache. LINSE (Linguistik-Server Essen), 29.

[10] Trudgill, P. (2000). Sociolinguistics: An Introduction to Language and Society. Penguin, 222.

[11] Ransmayr, J. (2006). Der Status des Österreichischen Deutsch an nichtdeutschsprachigen Universitäten. Eine empirische Untersuchung. Frankfurt am Main: Peter Lang, 326

[12] Reiffenstein I. (1995). Das Österreichische Wörterbuch: Zielsetzungen und Funktionen. Österreichisches Deutsch - Linguistische, sozialpsychologische und sprachpolitische Aspekte einer nationalen Variante des Deutschen / Rudolf Muhr, Richard Schrodt, Peter Wiesinger. Wien: Hцlder-Pichler-Tempsky, 158-165.

[13] Reiffenstein, I. (1973). Österreichisches Deutsch. Haslinger A. Deutsch heute. Linguistik - Literatur - Landeskunde / Adolf Haslinger. München, 19-26.

[14] Sarandin, A. V. (2004). Austriazismen im „Neuen deutsch-russischen Großwörterbuch”. Germanistisches Jahrbuch GUS „Das Wort", 369-380.

[15] Sedlaczek, R. (2004). Das österreichische Deutsch : wie wir uns von unserem großen Nachbarn unterscheiden; ein illustriertes Handbuch. Ueberreuter, 496.

[16] Weiss Andreas E., Weiss Gerlinde. Das österreichische Deutsch. Das österreichische Deutsch - eine Standardvariante der deutschen Sprache. Salzburg: Hausdruckerei, 5-14.

[17] Wiesinger, P. (1988). Die deutsche Sprache in Österreich. Eine Einführung. Das österreichische Deutsch. Wien; Köln; Graz: Bühlau, 225-245.

[18] Vorontsova, N. K. (2016). Vliyanie avstritsizmov na literaturnuyu normu nemetskogo yazyka. Teoreticheskie i prakticheskie problemy razvitiya sovremennoy nauki: sbornik materialov 12-y mezhdunarodnoy nauch.-prakt. konf., Mahachkala: Izdatel'stvo «Aprobatsiya», 79-80.

[19] Andreeva, T. V., Kirillova, O. Yu. (2018). Yazykovye osobennosti avstriyskogo varianta nemetskogo yazyka (na primere sbornika rasskazov "sobytie po-avstriyski”). Voprosy obshchego yazykoznaniya i teorii teksta, 11-14.

[20] Leshanova, O. A., Malkina, A. P. (2016). Leksiko-semanticheskie osobennosti avstriyskogo varianta nemeckogo yazyka (na primere imen sushestvitelnyh). Materialy XX nauchno-prakticheskoy konferencii molodyh uchenyh, aspirantov i studentov Nacionalnogo issledovatelskogo Mordovskogo gosudarstvennogo universiteta im. N. P. Ogaryova v 3-h chastyah, 472-476.

[21] Lanskih, Yu. V. (2014) Avstriyskiy nemetskiy ili o chem ne znaet Duden. Vestnik TvGU. Seriya: Filologiya, 2, $62-67$. 